\title{
ALU repeat as potential molecular marker in the detection and prognosis of different cancer types: A systematic review
}

\author{
SEMAA A. SHABAN ${ }^{1}$, AYA M. AL-RAHIM ${ }^{2}$ and AHMED ABDULJABBAR SULEIMAN ${ }^{3}$ \\ ${ }^{1}$ Department of Biology, College of Sciences, Tikrit University, Tikrit, Saladin 34001; \\ ${ }^{2}$ Department of Molecular and Medical Biotechnology, College of Biotechnology, Al-Nahrain University, Baghdad 64074; \\ ${ }^{3}$ Department of Biotechnology, Science College, University of Anbar, Ramadi, Anbar 46006, Iraq
}

Received December 3, 2021; Accepted January 13, 2022

DOI: $10.3892 / \mathrm{mco} .2022 .2519$

\begin{abstract}
Cancer is a major health issue worldwide. cfDNA integrity has been reported as a potential diagnostic molecular marker for different types of cancer, identifying the importance of liquid biopsy. The aim of this review was to evaluate the prognostic and diagnostic performance of Arthrobacter luteus (ALU) repeat in tumor. Following a thorough review of the literature published from January, 2000 to September 2021, 36 studies were included. All of the study descriptions were analyzed. According to several studies, there were increased concentrations of ALU repetitive elements in cancer patients, while these concentrations were decreased in control, benign, different cancer stage, and other diseases. The total ALU (115 and 247) sequence levels are potential biomarkers for the purpose of investigations and cancer prognosis.
\end{abstract}

\section{Introduction}

In both developed and developing countries, cancer is a major health issue and a leading cause of mortality that is still on the increase, worldwide. According to the International Agency for Research on Cancer, in 2018, 9.6 million individuals died from cancer, an increase from 8.2 million in 2012 and 7.6 million in 2008 (1-3). Tumorigenesis is a multi-step, multi-factorial disease described by genetic and epigenetic changes, which is difficult to control and prevent (4). In 2012, the WHO's International Agency for Research on Cancer predicted that by 2030 , worldwide, there would be 21.7 million newly diagnosed cancer cases and 13 million cancer deaths as a result of population growth and the increase in life expectancy (5).

Cancer is a major health problem that affects individuals globally. Several types of cancer can be avoided if diagnosed

Correspondence to: Dr Ahmed Abduljabbar Suleiman, Department of Biotechnology, Science College, University of Anbar, Tameen, Anbar University Campus, Ramadi, Anbar 46006, Iraq E-mail: ahmed.suleiman@uoanbar.edu.iq

Key words: cell-free DNA, Arthrobacter luteus sequences, cancer, liquid biopsy, biomarker early enough. However, tumors such as lung, colon, and breast cancers frequently have late-stage diagnosis. Despite efforts to ensure survival is prolonged, only a moderate improvement has been achieved in cancer patients. Failure to diagnose cancer early generally leads to ineffective treatment and an even worse prognosis. The availability of robust diagnostic biomarkers is critical for diagnosing cancer patients at an early stage and thereby greatly reducing overall mortality rates. (6).

Circulating molecular biomarkers have increasingly been used as a liquid biopsy in the peripheral blood and have the benefit of being easily accessible, with early detection, and reproducibility (7). Circulating tumor cells, circulating DNA, and microRNAs have been studied as a detection tool and prognosis of various cancer types (8-13).

DNA is a molecule that may be found inside and outside of cells. Extracellular DNA can be found in blood and other body fluids. Cell-free DNA refers to the degraded DNA fragments floating in the circulation (cfDNA). DNA in the bloodstream releases apoptotic or necrotic cells. The length of DNA fragments and distribution of DNA size could signify cfDNA source (14). Apoptosis of the cell naturally occurs, and DNA is divided into similar fragments of 185-200 bp. However, tumor necrosis produces similar fragments of DNA in variable lengths generally $>200$ bp (15). Circulating tumor DNAs (ctDNAs) based DNA integrity index served as a possible indicator of prognosis in hepatocellular carcinoma, lymphoma, colorectal, lung, and breast cancer (15-19). DNA analysis can be conducted on the basis of ctDNA (from a liquid biopsy) as well as directly isolated DNA from tumor tissue acquired by biopsy or excision (20).

According to Iqbal et al (21) presence of cfDNA in blood, although reported in 1948 by Mandel and Metais (22), was rediscovered after 30 years in autoimmune disorders by Tan et al in 1966 (23) and in cancer by Leon et al in 1977 (24).

Apoptosis is the source of cfDNA in a healthy person, raising shorter and evenly sized DNA fragments. Furthermore, in cancer, necrosis results in unequal longer DNA fragments in addition to the shorter apoptotic fragment (25-27). As a result, higher levels of longer DNA fragments in the blood have been identified as a useful indicator of the existence of malignant tumor DNA (26-28). The cfDNA concentration in serum is higher in patients with cancer when compared to healthy individuals (5,29-31). 
The variability of cfDNA levels in patients is most probably associated with tumor stage, burden, cellular turnover, vascularity, and response to therapy with the highest levels reported in patients with metastatic and advanced disease (32).

cfDNA levels have been found to be elevated in a variety of cancers (7). One measure of cfDNA fragmentation is cfDNA integrity (cfDI), which is calculated as the ratio of longer to shorter DNA fragment concentrations at the same genetic location (29).

A liquid biopsy is a viable alternative consisting of the circulating analysis (cfDI). This main advantage of this method is that it is less invasive, using just a sample of peripheral blood. During the past two decades, cfDI analysis has emerged as a promising tool for cancer diagnosis and prognosis $(33,34)$.

The Arthrobacter luteus (ALU) repeats are the most predominant repetitive sequences in the human genome, 300 bp in length, with $1.4 \times 10^{6}$ copy number per genome. Most studies used DNA integrity, defined as the ratio of ALU 247 long fragments released from necrotic cells and ALU 115 short fragments released from normal cells (35).

ALU-quantitative PCR (qPCR) has become the most widely used technology for detecting the DNA integrity index (32). ALU covers over $10 \%$ of the human genome (36). Research has been conducted to assess the potential use of cfDI from the ALU variable as a diagnostic biomarker for a variety of cancers, such as breast and prostate cancer (37).

A higher portion of longer DNA fragments has been recommended as a cancer detection biomarker (26). Several formulae have been presented to objectively calculate the 'DNA integrity index' as a ratio of longer and smaller fragments. Umetani et al $(27,38)$ determined the pure ratio of ALU 247 and ALU 115 concentrations in patients' blood, while Wang et al (39) assessed DNA integrity in patient plasma using a calculation based on delta-Cp values. Patients with ovarian, breast and colorectal cancer had higher DNA integrities in serum and plasma than controls, according to both authors $(27,38)$. Other studies, on the other hand, could not find a difference in DNA integrity values in the same tumor types (40-42).

However, in different studies, the performance of ALU repeat as a biomarker for cancer diagnosis varied widely. Therefore, this systematic study, to the best of our knowledge, is the first to clarify the diagnostic and prognostic role of ALU elements as a molecular marker of cancer.

\section{Materials and methods}

Strategy of search and study selection. A search for potentially suitable articles was performed on the PubMed online databases up to September 2021, for research articles. The following keyword combinations were included in the detailed search strategy: ('ALU' OR 'cfDNA') AND ('cancer' OR 'tumor'). Studies were considered for selection if they included information on ALU sequences and their potential role in the diagnosis or prognosis of different types of cancer. Studies not in English or where only the abstract was available were excluded. Initially, data extraction was carried out by two of the authors (AS and SS). The full-text articles were then obtained for more evaluation. The reference lists of all of the studies were manually checked by the authors to identify additional publications that may be of interest.
The studies that were determined to be eligible were as follows: a plan for an observational, assessing the relationship between ALU and the role in diagnosis or prognosis of cancer, there was enough information to assess the difference in ALU levels between the patients and the controls and between cancer stage.

Collection of data and quality assessment. Authors extracted data independently from each eligible study and abstracted the following information including cancer type, sample type, DNA size ratio. The data were evaluated for each group, and the main results identified.

Included studies. The PubMed search identified 250 articles. After the initial inclusion of 150 articles (based on title and abstract were selected for assessment), 32 articles were excluded due to not meeting the criteria for inclusion (including ALU methylation, comparison between ALU and LINE, and studies in other languages). A manual search of the references of studies on the subject yielded 15 additional articles. A total of 133 articles were included for the full text assessment, in English. The selection of the study flowchart is presented in Fig. 1.

\section{Results}

Included studies. The PubMed search initially identified 250 articles. Based on title and abstract 150 articles were selected for assessment, of which 32 articles were excluded due to not meeting the criteria for inclusion. Further manual search of the references yielded 15 additional articles. A total of 133 articles were included for the full text assessment (Fig. 1).

Overall characteristics. The characteristics of the studies that were included are shown in Table I, which shows the number of tumor cases (16-268) and healthy controls (12-110). The subjects' age range was $18-71$ years. There were 16 studies from European countries (44.4\%), 12 from Asia (33.3\%), 6 from Africa (16.7\%), and 2 from the USA (5.6\%). These studies focused on carcinoma, including breast, lung, prostate, ovarian, endometrial, pancreatic, and thyroid cancer. To determine the value of cfDI, all of the included studies used the quantitative PCR (qPCR) method, 14 of them were evaluated in serum and 19 in plasma, 1 (in serum and plasma), 1 in tissue, and 1 in urine. cfDI was calculated as the ratio of longer DNA fragment concentrations to shorter ones in the same locus. The reference list included 35 articles, published between 2006 and 2021.

ALU as diagnostic or prognostic biomarker in cancer. When comparing cancer cases with control in 36 articles, in 12 studies, the levels of ALU 247 and ALU 115 were higher in patients than in controls. Thus, in total, 11 studies were retained, with cfDI higher in cancer patients than the healthy controls (an association between a higher cfDI and tumor stage, as well as high sensitivity was identified in 3 of 12 articles) and 4 had no cfDI difference.

Table I shows 11 studies had only diagnostic and 8 had only prognostic information, and 5 articles from the cancer group had significantly higher concentrations of ALU sequences and cfDI than the benign disease group. Six studies monitoring the 
Table I. List of studies evaluating ALU in cancer.

\begin{tabular}{|c|c|c|c|c|}
\hline Cancer type & No. of subjects & $\begin{array}{l}\text { Source of } \\
\text { DNA }\end{array}$ & $\begin{array}{l}\text { Ratio of } \\
\text { DNA size }\end{array}$ & Conclusions \\
\hline Breast cancer & $\begin{array}{l}\text { (51) Controls } \\
\text { (83) Preoperative } \\
\text { (Stage } 0 \text { to IV primary BC) }\end{array}$ & Serum & $\begin{array}{c}\text { ALU } \\
247 / 115\end{array}$ & $\begin{array}{l}\text { Serum circulating cfDI is a potential } \\
\text { molecular biomarker for detecting the } \\
\text { progression of } \mathrm{BC} \text { and lymph node } \\
\text { metastases }\end{array}$ \\
\hline Breast cancer & $\begin{array}{l}\text { (49) Controls } \\
\text { (39) BC patients }\end{array}$ & Plasma & $\begin{array}{c}\text { ALU } \\
247 / 115\end{array}$ & $\begin{array}{l}\text { According to the results, necrosis could be } \\
\text { a possible source of cfDNA ALU } 247 \text {; } \\
\text { and a tumor biology phenotypic feature }\end{array}$ \\
\hline Breast cancer & $\begin{array}{l}\text { (65) BC patients undergoing } \\
\text { neoadjuvant chemotherapy } \\
\text { No controls reported }\end{array}$ & Plasma & $\begin{array}{c}\text { ALU } \\
247 / 115\end{array}$ & $\begin{array}{l}\text { The study indicates circulating DNA } \\
\text { biomarkers ALU ( } 115 \text { and } 247 \text { ) as two } \\
\text { potential future markers for the assessment } \\
\text { of neoadjuvant chemotherapy response } \\
\text { in BC patients }\end{array}$ \\
\hline Breast cancer & $\begin{array}{l}\text { (28) Controls } \\
\text { (12) Benign BC patients, } \\
\text { (65) Locally confined BC }\end{array}$ & Plasma & $\begin{array}{c}\text { ALU } \\
247 / 115\end{array}$ & $\begin{array}{l}\text { Plasma DNA is helpful in the diagnosis of } \\
\text { locally BC, however, in MBC, established } \\
\text { tumor markers are the most informative }\end{array}$ \\
\hline
\end{tabular}

(Refs.) patients

(47) Metastatic breast cancer patients

$\begin{array}{ll}\text { Breast cancer } & \text { (100) Controls } \\ & \text { (82) Primary BC patients } \\ & \text { (201) MBC patients }\end{array}$

Plasma

ALU Study shows that cfDI was reduced and 260/111 cfDNA level increased can be used as diagnostic biomarkers for both primary and metastatic breast cancer, and cfDI as an MBC prognostic marker, as a result, they're good candidates for blood-based multi-marker tests

$\begin{array}{lll}\text { Breast cancer } & \text { (51) Controls } & \text { Serum } \\ & \text { (148) BC patients } & \\ & \text { (148) Baseline } & \\ & \text { (47) Postoperative } & \\ \text { Breast cancer } & \text { (175) Non-recurrent } & \text { Plasma } \\ & \text { BC patients } & \\ & \text { (7) recurrent-BC patients } & \\ \text { Breast cancer } & \text { No controls reported } & \\ & \text { (268) MBC patients } & \text { Plasma }\end{array}$

ALU In patients with primary BC, cfDNA level

247/115 and cfDI were found to represent potential prognostic markers

ALU In the clinic, cfDI could be a helpful 260/111 biomarker for prognosis of BC recurrence when combined with other molecular markers

No controls reported

ALU At baseline and during systematic therapy, 260/111 cfDNA variables can serve as attractive prognostic markers for MBC patients, especially when combined with other markers

$\begin{array}{ll}\text { Breast cancer } & \text { (10) Controls } \\ & \text { (40) BC patients (2: stage I, } \\ & \text { 31: stage II, 2: stage III, } \\ & \text { and 5: stage IV) } \\ & \text { (64) Females } \\ \text { Breast and } & \text { (Consisting of 32 controls 32 } \\ \text { prostate cancers } & \text { and BC patients) } \\ & \text { and (61) Males } \\ & \text { (Consisting of 30 controls } \\ & \text { and 31 prostate cancer patients) }\end{array}$

Breast and lung

(64) Controls

Plasma

ALU Both ALU 247 and ALU 115 appear to be 247/115 prognostic markers for BC preoperative

Serum

ALU cfDI increased with disease severity and 247/115 higher staging in the prostate but not in BC

cancers

(64) BC patients

Plasma

ALU This study suggested ALU index could be 263/58 used as a test to discriminate cancer patients

(64) Lung cancer patients 
Table I. Continued.

\begin{tabular}{|c|c|c|c|c|}
\hline Cancer type & No. of subjects & $\begin{array}{l}\text { Source of } \\
\text { DNA }\end{array}$ & $\begin{array}{l}\text { Ratio of } \\
\text { DNA size }\end{array}$ & Conclusions \\
\hline Prostate cancer & $\begin{array}{l}\text { (96) PC patients } \\
\text { (112) Benign prostate } \\
\text { hyperplasia }\end{array}$ & Plasma & $\begin{array}{c}\text { ALU } \\
247 / 115\end{array}$ & $\begin{array}{l}\text { cfDNA and cfDI could be used to } \\
\text { differentiate PC from BPH in patients with } \\
\text { serum PSA C } 4 \mathrm{ng} / \mathrm{ml}\end{array}$ \\
\hline Prostate cancer & $\begin{array}{l}\text { (30) Controls } \\
\text { (50) PC patients } \\
\text { (25) BPH }\end{array}$ & Serum & $\begin{array}{c}\text { ALU } \\
247 / 115\end{array}$ & $\begin{array}{l}\text { ALU } 115 \text { could be a useful biomarker for } \\
\text { identifying patients that are at high risk, } \\
\text { pointing to early tumor cell spread as a } \\
\text { possible seed for future metastases }\end{array}$ \\
\hline Prostate cancer & $\begin{array}{l}\text { (30) Controls } \\
\text { (30) PC patients } \\
\text { (40) BPH }\end{array}$ & Plasma & $\begin{array}{c}\text { ALU } \\
247 / 115\end{array}$ & $\begin{array}{l}\text { A significant relationship between cfDNA } \\
\text { concentration, its integrity, and PC suggests } \\
\text { that the liquid biopsy can be usedas a non- } \\
\text { invasive early diagnostic biomarker }\end{array}$ \\
\hline Ovarian cancer & $\begin{array}{l}\text { (12) Controls } \\
\text { (24) Ovariancancer patients } \\
\text { (12) Benign ovarian cysts } \\
\text { patients }\end{array}$ & Plasma & $\begin{array}{c}\text { ALU } \\
219 / 115\end{array}$ & $\begin{array}{l}\text { Monitoring ALU concentrations, alone or in } \\
\text { combination with other tumor markers, could } \\
\text { be used for subsidiary diagnosis and prognosis } \\
\text { of ovarian cancer }\end{array}$ \\
\hline Ovarian cancer & $\begin{array}{l}\text { (28) Controls } \\
\text { (37) Ovarian cancer patients }\end{array}$ & Plasma & $\begin{array}{c}\text { ALU } \\
260 / 111\end{array}$ & $\begin{array}{l}\text { In combination with other molecular markers, } \\
\text { cfDNA variables could be used as diagnostic } \\
\text { biomarkers in ovarian cancer }\end{array}$ \\
\hline $\begin{array}{l}\text { Endometrial } \\
\text { cancer }\end{array}$ & $\begin{array}{l}\text { (15) Controls } \\
\text { (53) EC patients } \\
\text { (9) Benign gynecologic } \\
\text { disease patients }\end{array}$ & Plasma & - & $\begin{array}{l}\text { Although cfDNA measurement is not effective } \\
\text { for EC screening, the change in cfDNA in a } \\
\text { patient could be a prognostic biomarker for EC }\end{array}$ \\
\hline $\begin{array}{l}\text { Endometrial } \\
\text { cancer }\end{array}$ & (60) Controls and EC patients & Serum & $\begin{array}{c}\text { ALU } \\
247 / 115\end{array}$ & $\begin{array}{l}\text { The study noted the potential use of serum } \\
\text { cfDI as a noninvasive molecular biomarker } \\
\text { in EC. And a correlation analysis between } \\
\text { cfDNA quantitative and qualitative content } \\
\text { and clinicopathologic characteristics, such as } \\
\text { body mass index, blood pressure level, and } \\
\text { lymphovascular space invasion status }\end{array}$ \\
\hline $\begin{array}{l}\text { Endometrial } \\
\text { cancer }\end{array}$ & $\begin{array}{l}\text { (32) EC patients } \\
\text { No controls reported }\end{array}$ & Plasma & $\begin{array}{c}\text { ALU } \\
247 / 115\end{array}$ & $\begin{array}{l}\text { Decreased plasma cfDI during vaccination and } \\
\text { the cfDI was related to prognosis. Another } \\
\text { cancer study has confirmed some of these } \\
\text { findings, as a result, the cfDI could be a } \\
\text { potential biomarker for future cancer } \\
\text { vaccination therapies }\end{array}$ \\
\hline $\begin{array}{l}\text { Pancreatic } \\
\text { malignancies }\end{array}$ & $\begin{array}{l}\text { (23) Controls } \\
\text { (50) Pancreatic } \\
\text { ductal adenocarcinoma patients } \\
\text { (23) Pancreatic neuroendocrine } \\
\text { tumor patients } \\
\text { (20) Chronic pancreatitis } \\
\text { patients }\end{array}$ & Plasma & $\begin{array}{c}\text { ALU } \\
244 / 83\end{array}$ & $\begin{array}{l}\text { The lack of detectable cfDNA levels in } \\
\text { pancreatic diseases has a significant impact on } \\
\text { the clinical usage of such a biomarker in } \\
\text { pancreatic ductal adenocarcinoma patients } \\
\text { When evaluating the diagnostic value of } \\
\text { cfDNA in pancreas pathology, different } \\
\text { methods of analysis should be used }\end{array}$ \\
\hline $\begin{array}{l}\text { Pancreatic } \\
\text { cancer }\end{array}$ & $\begin{array}{l}\text { (19) Controls } \\
\text { (19) Pancreatic } \\
\text { cancer patients }\end{array}$ & Serum & $\begin{array}{c}\text { ALU } \\
247 / 115\end{array}$ & $\begin{array}{l}\text { cfDI is not a useful biomarker to detect } \\
\text { premalignant pancreatic tumors }\end{array}$ \\
\hline $\begin{array}{l}\text { Pancreatic } \\
\text { cancer }\end{array}$ & $\begin{array}{l}\text { (32) Control adjacent } \\
\text { pancreatic tissue specimens } \\
\text { (42) The tumors samples }\end{array}$ & Tissue & $\begin{array}{c}\text { ALU } \\
247 / 115\end{array}$ & $\begin{array}{l}\text { cfDI (ALU } 247 / 115 \text { ratio) was no } \\
\text { significant difference between pancreatic } \\
\text { cancer patients and controls }\end{array}$ \\
\hline $\begin{array}{l}\text { Colorectal } \\
\text { cancer and } \\
\text { periampullary } \\
\text { cancer }\end{array}$ & $\begin{array}{l}\text { (51) Controls } \\
\text { (32) CRC patients } \\
\text { (19) Periampullary } \\
\text { cancer patients }\end{array}$ & Serum & $\begin{array}{c}\text { ALU } \\
247 / 115\end{array}$ & $\begin{array}{l}\text { cfDI is a promising serum biomarker for } \\
\text { colorectal and periampullary cancer } \\
\text { detection and evaluation }\end{array}$ \\
\hline
\end{tabular}


Table I. Continued.

\begin{tabular}{|c|c|c|c|c|}
\hline Cancer type & No. of subjects & $\begin{array}{l}\text { Source of } \\
\text { DNA }\end{array}$ & $\begin{array}{l}\text { Ratio of } \\
\text { DNA size }\end{array}$ & Conclusions \\
\hline $\begin{array}{l}\text { Colorectal } \\
\text { cancer }\end{array}$ & $\begin{array}{l}\text { (35) Patients without } \\
\text { endoscopic abnormality } \\
\text { (26) Benign colorectal } \\
\text { adenomas patients } \\
\text { (24) CRC patients }\end{array}$ & $\begin{array}{l}\text { Serum } \\
\text { and } \\
\text { plasma }\end{array}$ & $\begin{array}{c}\text { ALU } \\
247 / 115\end{array}$ & $\begin{array}{l}\text { In patients with positive fecal occult blood tests, } \\
\text { the circulating marker, in combination with other } \\
\text { markers, offers the possibility of a simple blood } \\
\text { test as a secondary screen for CRC and polyps }\end{array}$ \\
\hline $\begin{array}{l}\text { Colorectal } \\
\text { cancer }\end{array}$ & $\begin{array}{l}\text { (24) Controls } \\
\text { (24) CRC patients } \\
\text { (11) Benign gastrointestinal } \\
\text { diseases patients }\end{array}$ & Serum & $\begin{array}{c}\text { ALU } \\
247 / 115\end{array}$ & $\begin{array}{l}\text { cfDI is significantly higher in CRC patients } \\
\text { and could be useful in future studies }\end{array}$ \\
\hline $\begin{array}{l}\text { Colorectal } \\
\text { cancer }\end{array}$ & $\begin{array}{l}\text { (110) Controls } \\
\text { (104) Primary CRC patients } \\
\text { (85) Operated colorectal } \\
\text { cancer patients } \\
\text { (16) Recurrent/metastatic } \\
\text { CRC patients } \\
\text { (63) Intestinal polyps' } \\
\text { patients }\end{array}$ & Serum & $\begin{array}{c}\text { ALU } \\
247 / 115\end{array}$ & $\begin{array}{l}\text { Combined with ALU 115, the ratio of ALU } \\
247 / 115 \text { and carcinoembryonic antigen detection } \\
\text { could enhance CRC diagnostic efficiency. Serum } \\
\text { cfDNA and cfDI may be valuable in early } \\
\text { diagnosis and monitoring of CRC progression } \\
\text { and prognosis }\end{array}$ \\
\hline $\begin{array}{l}\text { Colorectal } \\
\text { cancer }\end{array}$ & $\begin{array}{l}\text { (20) Controls } \\
\text { (50) CRCpatients } \\
\text { (10) Benign colonic } \\
\text { polyp's patients }\end{array}$ & Serum & $\begin{array}{c}\text { ALU } \\
247 / 115\end{array}$ & $\begin{array}{l}\text { As a potential serum biomarker, the cfDI } \\
\text { outperforms the absolute DNA level for CRC } \\
\text { diagnosis. It could also be used as a marker for } \\
\text { monitoring the progression of CRC patients }\end{array}$ \\
\hline $\begin{array}{l}\text { Colorectal } \\
\text { cancer }\end{array}$ & $\begin{array}{l}\text { (56) Controls } \\
\text { (114) CRC patients } \\
\text { (22) Adenomatous } \\
\text { lesion patients }\end{array}$ & Serum & $\begin{array}{c}\text { ALU } \\
244 / 83\end{array}$ & $\begin{array}{l}\text { Serum cfDNA concentrations may be an } \\
\text { effective source of non-invasive cancer } \\
\text { biomarkers }\end{array}$ \\
\hline $\begin{array}{l}\text { Colorectal } \\
\text { cancer }\end{array}$ & $\begin{array}{l}\text { (30) Controls } \\
\text { (90) CRC patients } \\
\text { (30) Benigncolorectal } \\
\text { mass patients }\end{array}$ & Serum & $\begin{array}{c}\text { ALU } \\
247 / 115\end{array}$ & $\begin{array}{l}\text { According to the study, cfDI is better to } \\
\text { carcinoembryonic antigen as an early biomarker } \\
\text { for detecting CRC and its potential to be } \\
\text { employed as a biomarker for malignancy }\end{array}$ \\
\hline $\begin{array}{l}\text { Colorectal } \\
\text { cancer }\end{array}$ & $\begin{array}{l}\text { (76) Primary CRC patients } \\
\text { who underwent surgery, } \\
\text { including (60) with } \\
\text { chemotherapy and (43) with }\end{array}$ & Serum & $\begin{array}{c}\text { ALU } \\
247 / 115\end{array}$ & $\begin{array}{l}\text { Serum cfDI may be a promising candidate } \\
\text { biomarker for prognostic prediction in CRC } \\
\text { patients who have had chemotherapy and } \\
\text { are being followed-up for a short time }\end{array}$ \\
\hline
\end{tabular}

(Refs.)

No controls reported

cancer (38) Malignant lesions

patients

No controls reported

Plasma

ALU Measured the integrity index in the vein draining

$247 / 115$ the thyroid is similar to that measured in the antecubital vein, using a peripheral liquid biopsy to validate cfDI measurements. In opposition to its diagnostic efficacy in aggressive cancers, cfDI has limited utility as a biomarker of malignancy in cytologically indeterminate thyroid nodules

$\begin{array}{ll}\begin{array}{l}\text { Non-small } \\ \text { cell lung } \\ \text { cancer }\end{array} & \begin{array}{l}\text { (60) Controls } \\ \text { cancer patients } \\ \text { (40) Chronic obstructive }\end{array} \\ & \begin{array}{l}\text { pulmonary disease patients } \\ \text { Non-small } \\ \text { (107) Controls }\end{array} \\ \text { cancer } & \text { (106) NSCLCpatients } \\ & \text { (105) Tuberculosis patients }\end{array}$

Serum

ALU

Serum cfDNA level, its integrity may be an

$247 / 115$ effective tool of NSCLC early diagnosis and prognosis of the disease

Plasma

ALU

NSCLC may be identified from tuberculosis 247/115

Furthermore, the integrity index had a significant effect on traditional tumor markers in distinguishing NSCLC from tuberculosis 
Table I. Continued.

\begin{tabular}{|c|c|c|c|c|c|}
\hline Cancer type & No. of subjects & $\begin{array}{l}\text { Source of } \\
\text { DNA }\end{array}$ & $\begin{array}{l}\text { Ratio of } \\
\text { DNA size }\end{array}$ & Conclusions & (Refs.) \\
\hline $\begin{array}{l}\text { Non-small } \\
\text { cell lung } \\
\text { cancer }\end{array}$ & (130) NSCLC patients & Plasma & $\begin{array}{c}\text { ALU } \\
247 / 115\end{array}$ & $\begin{array}{l}\text { The findings show that cfDI could be used as a } \\
\text { prognostic biomarker in patients who received } \\
\text { a personalized peptidevaccine }\end{array}$ & $(62)$ \\
\hline Lung cancer & $\begin{array}{l}\text { (19) Controls } \\
\text { (29) Lung cancer patients }\end{array}$ & Plasma & $\begin{array}{c}\text { ALU } \\
247 / 115\end{array}$ & $\begin{array}{l}\text { The study suggests that ALU repeat ratios could } \\
\text { be used for prognostic purposes in the advanced } \\
\text { setting for patients of lung cancer patients }\end{array}$ & (15) \\
\hline Lung cancer & $\begin{array}{l}\text { (35) Controls } \\
\text { (55) Lung cancer patients }\end{array}$ & Urine & $\begin{array}{l}\text { ALU-60, } \\
115 \text { and } \\
247\end{array}$ & $\begin{array}{l}\text { cfDNA concentration index could serve as } \\
\text { promising diagnostic biomarkers for lung cancer }\end{array}$ & $(63)$ \\
\hline
\end{tabular}

ALU, Arthrobacter luteus; BC, breast cancer; MBC, metastatic breast cancer; PC, prostate cancer; $\mathrm{BPH}$, benign prostate hyperplasia; EC, endometrial cancer; CRC, colorectal cancer; NSCLC, non-small cell lung cancer; cfDNA, cell-free DNA; cfDI, circulating-free DNA integrity.

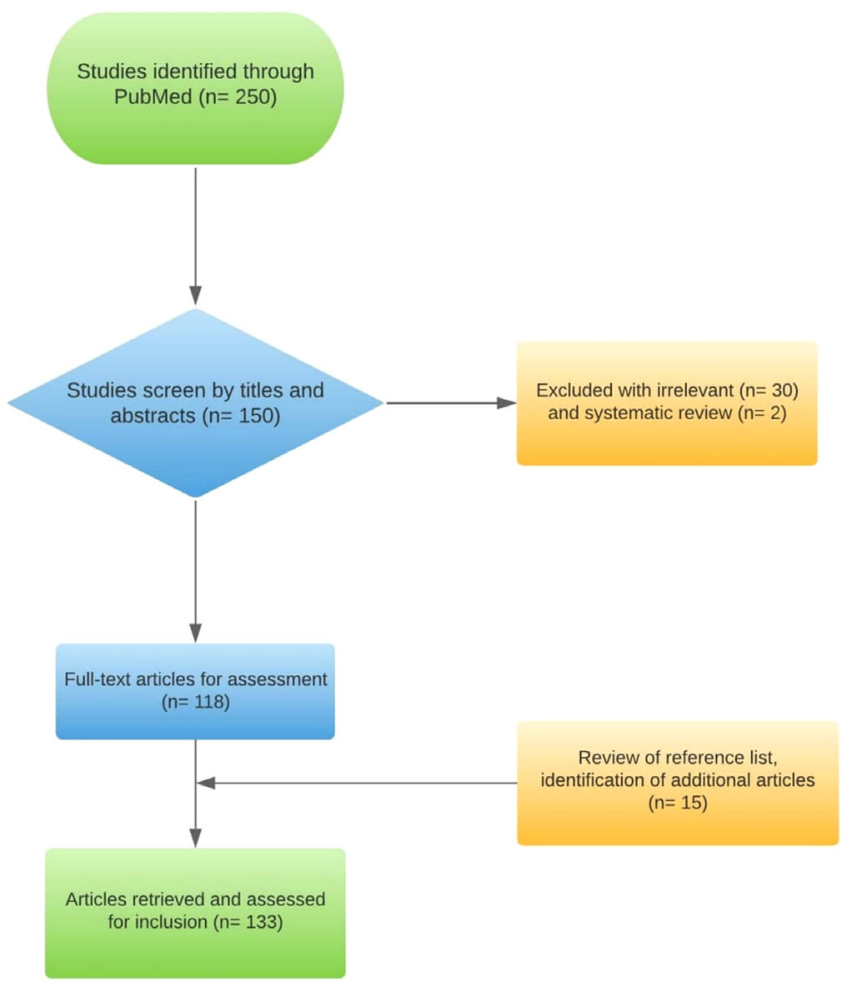

Figure 1. Flowchart of the present study showing how the 133 articles were selected.

ALU level could be applied for subsidiary cancer diagnosis, either alone or in combination with additional tumor markers.

For other ALU, including ALU 260/111, the cfDNA variables can serve as attractive prognostic markers for metastatic cancer during therapy. In addition, although ALU 244/83 is a potential biomarker, there are currently no extensive studies to verify this hypothesis (Table I).

\section{Discussion}

Cancer is a major global health problem due to the increasing incidence and fatality rates. An early cancer diagnosis is crucial as it can improve the chances of survival for cancer patients and decrease the mortality rate. At present, liquid biopsies are promising due to their potential advantages, including reliability, easy access, and reproducibility (11).

In the present review, several studies supported the use of liquid biopsy in cancer as being innovative. To determine whether this liquid biopsy could assist the diagnostic or assessment of treatment response, 36 articles were included to identify the ALU sequences as a biomarker in cancer. The limitations of data retrieved are mostly related to the 36 articles as there is great heterogeneity in studies, it is difficult to analyse the subgroup study, the articles constitute a small sample size, little research highlighting the differences of ALU and cfDI at different stages is available, and the cut-off values vary widely between studies and were missing in other studies.

The present review identified the role of ALU element in cancer progression. Collectively, our data indicated that ALU elements can be used as a biomarker $(29,35,44,47,49,52,54,63)$. The use of cfDNA, for early diagnosis, prognosis biomarkers and monitoring of therapy have been a significant advancement in clinical medicine $(18,47,51,52,60-62)$.

As mentioned previously, not all studies have confirmed that ALU levels vary with tumor development and progression, which may elucidate that cancer is a heterogeneous disease.

cfDI was subsequently evaluated for its usefulness in cancer diagnosis and prognosis $(5,15,31,32,34,48,58)$. Higher cfDI values in cancer patients vs. healthy controls were identified in many studies $(31,34,57,58,61)$. By contrast, lower cfDI was observed in different studies; however, some articles with a focus on metastatic breast cancer $(10,45)$, recurrent breast cancer $(46)$, or first cycle of vaccination $(53,62)$ were few and inconsistent.

There are few studies highlight of the ALU 260/111 in cancer $(10,18,29,46)$ so is not possible to determinate the role of it as biomarker.

Several studies have identified an altered cfDI in patients compared to controls. However, these studies are heterogeneous, some studies showed a reduced cfDI in patients, while others reported an increased cfDI. Various hypotheses have been posited to understand the underlying reason. 
cfDNA from healthy individuals had 3- to 5-fold multiples of nucleosome-associated DNA length, and longer fragments than cfDNA from pancreatic cancer patients using direct visualization by gel electrophoresis (64). Jiang et al (64) found increased levels of shorter mitochondrial DNA molecules in the plasma of cancer patients compared to healthy people using massively parallel sequencing.

The present study included 36 studies with many discrepancies. This was due to the fact that they were highly heterogeneous studies and not all studies included different stages. In addition, not enough data were available for a specific cancer type and occasionally subjects were limited, there were differences in molecular methods used and source of samples could influence the results. This heterogeneity may affect clarification and whether ALU can act as a biomarker in cancer disease. Thus, further studies are needed to better clarify the role of the ALU element in specific subgroups.

In general, the results obtained from the present systematic review show that the expression of ALU-247 and ALU-115, and cfDI concentration is a rising trend associated with cancer and cancer stage. As a result, circulating cfDNA may be significantly related to tumor cell turnover and tumor progression, indicating biologic tumor aggressiveness. Thus, the circulating cfDI could be suitable for monitoring cancer progression. In addition, large and multicenter sample groups must be studied to corroborate the findings.

Liquid biopsy is becoming the focus of future tumor diagnosis and treatment research. It is less invasive and painful, can be collected in a short period of time, can be collected regardless of where the target organ is located, can be repeated continually, and can represent cancer volume in real-time. However, there are disadvantages, such as if the amount of cfDNA is insufficient, correct information may not be collected. Thus, analytical technology must be established, and the patient's condition or underlying disease may influence the results. Liquid biopsies, as with any other test method, involve large cohort studies to determine their efficacy and sensitivity to various disorders.

The limitation of the present study was mainly to mention the results of ALU and cfDI in blood samples without mentioning the in vitro information regarding ALU and cfDI. This aspect should be investigated in future work.

In summary, findings of the review suggest that cfDI can be a significant predictor of developing cancer in patients and could be a useful marker in a molecular, blood-based multi-marker assay.

The current systematic review assessed the total ALU sequence levels and its index are promising biomarkers for the purpose of investigation or prognosis of cancer. However, because of the heterogeneity between studies, the difference of ALU value in different cancers (type or stage) therefore makes it difficult to compare between different types of cancer. Further studies and meta-analyses are needed for the final conclusion to explore the diagnostic role of ALU in malignant diseases, especially when combined with other cancer biomarkers.

\section{Acknowledgements}

The authors would like to express deep thanks to the University of Anbar, College of Science, Department of Biotechnology for their assistance.

\section{Funding}

Not applicable.

\section{Availability of data and materials}

The data generated in the present study are included in the figures and/or tables of this article.

\section{Authors' contributions}

SAS, AMA-R and AAS conceived and planned the review. Data extraction was carried out by SAS and AAS. SAS, AMA-R and AAS evaluated the articles, manually checked references and wrote the review. All authors have read and approved the final manuscript. Data authentication is not applicable.

\section{Ethics approval and consent to participate}

Not applicable for systematic reviews.

\section{Patient consent for publication}

Not applicable.

\section{Competing interests}

The authors declare that they have no competing interests.

\section{References}

1. Ferlay J, Colombet M, Soerjomataram I, Mathers C, Parkin DM, Piñeros M, Znaor A and Bray F: Estimating the global cancer incidence and mortality in 2018: GLOBOCAN sources and methods. Int J Cancer 144: 1941-1953, 2019.

2. Parkin DM, Pisani P and Ferlay J: Global Cancer Statistics. CA Cancer J Clin 49: 33-64. 1, 1999.

3. Li Y, Gu M, Jing F, Cai S, Bao C, Wang J, Jin M and Chen K: Association between physical activity and all cancer mortality: Dose-response meta-analysis of cohort studies. Int J Cancer 138: 818-832, 2016.

4. Ye D, Jiang D, Zhang $X$ and Mao Y: Alu methylation and risk of cancer: A meta-analysis. Am J Med Sci 359: 271-280, 2020.

5. Arko-Boham B, Aryee NA, Blay RM, Owusu EDA, Tagoe EA, Doris Shackie ES, Debrah AB and Adu-Aryee NA: Circulating cell-free DNA integrity as a diagnostic and prognostic marker for breast and prostate cancers. Cancer Genet 235-236: 65-71, 2019.

6. Pan Y, Liu G, Zhou F, Su B and Li Y: DNA methylation profiles in cancer diagnosis and therapeutics. Clin Exp Med 18: 1-14, 2018.

7. Schwarzenbach H, Hoon DS and Pantel K: Cell-free nucleic acids as biomarkers in cancer patients. Nat Rev Cancer 11: 426-437, 2011.

8. Shen J, Stass SA and Jiang F: MicroRNAs as potential biomarkers in human solid tumors. Cancer Lett 329: 125-136, 2013.

9. Paterlini-Brechot P and Benali NL: Circulating tumor cells (CTC) detection: Clinical impact and future directions. Cancer Lett 253: 180-204, 2007.

10. Madhavan D, Wallwiener M, Bents K, Zucknick M, Nees J, Schott S, Cuk K, Riethdorf S, Trumpp A, Pantel K, et al: Plasma DNA integrity as a biomarker for primary and metastatic breast cancer and potential marker for early diagnosis. Breast Cancer Res Treat 146: 163-174, 2014.

11. Cuk K, Zucknick M, Heil J, Madhavan D, Schott S, Turchinovich A, Arlt D, Rath M, Sohn C, Benner A, et al: Circulating microRNAs in plasma as early detection markers for breast cancer. Int J Cancer 132: 1602-1612, 2013.

12. Cuk K, Zucknick M, Madhavan D, Schott S, Golatta M, Heil J, Marmé F, Turchinovich A, Sinn P, Sohn C, et al: Plasma MicroRNA panel for minimally invasive detection of breast cancer. PLoS One 8: e76729, 2013. 
13. Madhavan D, Zucknick M, Wallwiener M, Cuk K, Modugno C, Scharpff M, Schott S, Heil J, Turchinovich A, Yang R, et al: Circulating miRNAs as surrogate markers for circulating tumor cells and prognostic markers in metastatic breast cancer. Clin Cancer Res 18: 5972-5982, 2012.

14. Tuchalska-Czuroń J, Lenart J, Augustyniak J and Durlik M Clinical value of tissue DNA integrity index in pancreatic cancer. Surgeon 18: 269-279, 2020.

15. Chudasama DY, Aladag Z, Felicien MI, Hall M, Beeson J, Asadi N, Gidron Y, Karteris E and Anikin VB: Prognostic value of the DNA integrity index in patients with malignant lung tumors. Oncotarget 9: 21281-21288, 2018.

16. Li M, Jia Y, Xu J, Cheng X and Xu C: Assessment of the circulating cell-free DNA marker association with diagnosis and prognostic prediction in patients with lymphoma: A single-center experience. Ann Hematol 96: 1343-1351, 2017.

17. El Messaoudi S, Mouliere F, Du Manoir S, Bascoul-Mollevi C Gillet B, Nouaille M, Fiess C, Crapez E, Bibeau F, Theillet C, et al: Circulating DNA as a strong multimarker prognostic tool for metastatic colorectal cancer patient management care. Clin Cancer Res 22: 3067-3077, 2016.

18. Cheng J, Holland-Letz T, Wallwiener M, Surowy H, Cuk K, Schott S, Trumpp A, Pantel K, Sohn C, Schneeweiss A and Burwinkel B: Circulating free DNA integrity and concentration as independent prognostic markers in metastatic breast cancer. Breast Cancer Res Treat 169: 69-82, 2018.

19. Habeeb WH, Suleiman AA and Al-Hitawee HT: Exploration of the beta-actin DNA integrity index as early genetic marker of presence of breast cancer. Electron J Gen Med 17: em188, 2020.

20. Akca H, Demiray A, Yaren A, Bir F, Koseler A, Iwakawa R, Bagci G and Yokota J: Utility of serum DNA and pyrosequencing for the detection of EGFR mutations in non-small cell lung cancer. Cancer Genet 206: 73-80, 2013.

21. Iqbal S, Vishnubhatla S, Raina V, Sharma S, Gogia A, Deo SS, Mathur S and Shukla NK: Circulating cell-free DNA and its integrity as a prognostic marker for breast cancer. Springerplus 4 : $265,2015$.

22. Mandel P and Metais P: Nuclear Acids In Human Blood Plasma. C R Seances Soc Biol Fil 14: 241-243, 1948 (In French)

23. Tan EM, Schur PH, Carr RI and Kunkel HG: Deoxybonucleic acid (DNA) and antibodies to DNA in the serum of patients with systemic lupus erythematosus. J Clin Invest 45: 1732-1740, 1966.

24. Leon SA, Shapiro B, Sklaroff DM and Yaros MJ: Free DNA in the serum of cancer patients and the effect of therapy. Cancer Res 37: 646-650, 1977.

25. Fleischhacker $M$ and Schmidt B: Circulating nucleic acids (CNAs) and cancer-A survey. Biochim Biophys Acta 1775: 181-232, 2007.

26. Jahr S, Hentze H, Englisch S, Hardt D, Fackelmayer FO, Hesch RD and Knippers R: DNA fragments in the blood plasma of cancer patients: Quantitations and evidence for their origin from apoptotic and necrotic cells. Cancer Res 61: 1659-1665, 2001.

27. Umetani N, Giuliano AE, Hiramatsu SH, Amersi F, Nakagawa T, Martino S and Hoon DSB: Prediction of breast tumor progression by integrity of free circulating DNA in serum. J Clin Oncol 24 4270-4276, 2006.

28. Diehl F, Li M, Dressman D, He Y, Shen D, Szabo S, Diaz LA Jr, Goodman SN, David KA, Juhl H, et al: Detection and quantification of mutations in the plasma of patients with colorectal tumors. Proc Natl Acad Sci USA 102: 16368-16373, 2005.

29. Stamenkovic S, Cheng J, Surowy H, Burwinkel B and Gündert M: Circulating cell-free DNA variables as marker of ovarian cancer patients: A pilot study. Cancer Biomark 28 : 159-167, 2020.

30. Hao TB, Shi W, Shen XJ, Shen XJ, Qi J, Wu XH, Wu Y, Tang YY and Ju SQ: Circulating cell-free DNA in serum as a biomarker for diagnosis and prognostic prediction of colorectal cancer. $\mathrm{Br}$ J Cancer 111: 1482-1489, 2014

31. Leng S, Zheng J, Jin Y, Zhang H, Zhu Y, Wu J, Xu Y and Zhang P: Plasma cell-free DNA level and its integrity as biomarkers to distinguish non-small cell lung cancer from tuberculosis. Clin Chim Acta 477: 160-165, 2018

32. Vizza E, Corrado G, De Angeli M, Carosi M, Mancini E, Baiocco E, Chiofalo B, Patrizi L, Zampa A, Piaggio G and Cicchillitti L: Serum DNA integrity index as a potential molecular biomarker in endometrial cancer. J Exp Clin Cancer Res 37: 16,2018 .
33. Thakur S, Tobey A, Daley B, Auh S, Walter M, Patel D, Nilubol N, Kebebew E, Patel A, Jensen K, et al: Limited utility of circulating cell-free dna integrity as a diagnostic tool for differentiating between malignant and benign thyroid nodules with indeterminate cytology (Bethesda Category III). Front Oncol 9: 905, 2019.

34. Park MK, Lee JC, Lee JW and Hwang SJ: Alu cell-free DNA concentration, Alu index, and LINE-1 hypomethylation as a cancer predictor. Clin Biochem 94: 67-73, 2021.

35. Salem R, Ahmed R, Shaheen K, Abdalmegeed M and Hassan H: DNA integrity index as a potential molecular biomarker in colorectal cancer. Egypt J Med Hum Genet 21: 38, 2020.

36. Lander ES, Linton LM, Birren B, Nusbaum C, Zody MC, Baldwin J, Devon K, Dewar K, Doyle M, FitzHugh W, et al: Initial sequencing and analysis of the human genome. Nature 409: 860-921, 2001.

37. Cheng J, Tang Q, Cao X and Burwinkel B: Cell-free circulating DNA integrity based on peripheral blood as a biomarker for diagnosis of cancer: A systematic review. Cancer Epidemiol Biomarkers Prev 26: 1595-1602, 2017.

38. Umetani N, Kim J, Hiramatsu S, Reber HA, Hines OJ, Bilchik AJ and Hoon DSB: Increased integrity of free circulating DNA in sera of patients with colorectal or periampullary cancer: Direct quantitative PCR for ALU repeats. Clin Chem 52: 1062-1069, 2006.

39. Wang BG, Huang HY, Chen YC, Bristow RE, Kassauei K, Cheng CC, Roden R, Sokoll LJ, Chan DW and Shih IeM: Increased plasma DNA integrity in cancer patients. Cancer Res 63: 3966-3968, 2003

40. Holdenrieder S, Burges A, Reich O, Spelsberg FW and Stieber P: DNA integrity in plasma and serum of patients with malignant and benign diseases. Ann N Y Acad Sci 1137: $162-170,2008$

41. Boddy JL, Gal S, Malone PR, Shaida N, Wainscoat JS and Harris AL: The role of cell-free DNA size distribution in the management of prostate cancer. Oncol Res 16: 35-41, 2006

42. Schmidt B, Weickmann S, Witt C and Fleischhacker M: Integrity of cell-free plasma DNA in patients with lung cancer and nonmalignant lung disease. Ann N Y Acad Sci 1137: 207-213, 2008.

43. Agostini M, Enzo MV, Bedin C, Belardinelli V, Goldin E, Del Bianco P, Maschietto E, D'Angelo E, Izzi L, Saccani A, et al: Circulating cell-free DNA: A promising marker of regional lymphonode metastasis in breast cancer patients. Cancer Biomark 11: 89-98, 2012.

44. Lehner J, Stötzer OJ, Fersching D, Nagel D and Holdenrieder S: Circulating plasma DNA and DNA integrity in breast cancer patients undergoing neoadjuvant chemotherapy. Clin Chim Acta 425: 206-211, 2013.

45. Stötzer OJ, Lehner J, Fersching-Gierlich D, Nagel D and Holdenrieder S: Diagnostic relevance of plasma DNA and DNA integrity for breast cancer. Tumor Biol 35: 1183-1191, 2014.

46. Cheng J, Cuk K, Heil J, Golatta M, Schott S, Sohn C, Schneeweiss A, Burwinkel B and Surowy H: Cell-free circulating DNA integrity is an independent predictor of impending breast cancer recurrence. Oncotarget 8: 54537-54547, 2017.

47. Hussein NA, Mohamed SN and Ahmed MA: Plasma ALU-247, ALU-115, and cfDNA integrity as diagnostic and prognostic biomarkers for breast cancer. Appl Biochem Biotechnol 187: 1028-1045, 2019.

48. Feng J, Gang F, Li X, Jin T, Houbao H, Yu C and Guorong L: Plasma cell-free DNA and its DNA integrity as biomarker to distinguish prostate cancer from benign prostatic hyperplasia in patients with increased serum prostate-specific antigen. Int Urol Nephrol 45: 1023-1028, 2013.

49. Fawzy A, Sweify KM,El-Fayoumy HM and Nofal N: Quantitative analysis of plasma cell-free DNA and its DNA integrity in patients with metastatic prostate cancer using ALU sequence. J Egypt Natl Canc Inst 28: 235-242, 2016.

50. Khani M, Hosseini J, Mirfakhraie R, Habibi M, Azargashb E and Pouresmaeili F: The value of the plasma circulating cell-free DNA concentration and integrity index as a clinical tool for prostate cancer diagnosis: A prospective case-control cohort study in an Iranian population. Cancer Manag Res 11: 4549-4556, 2019.

51. Zhang R, Pu W, Zhang S, Chen L, Zhu W, Xiao L, Xing C and Li K: Clinical value of ALU concentration and integrity index for the early diagnosis of ovarian cancer: A retrospective cohort trial. PLoS One 13: e0191756, 2018. 
52. Tanaka H, Tsuda H, Nishimura S, Nomura H, Kataoka F, Chiyoda T, Tanaka K, Iguchi Y, Susumu N and Aoki D: Role of circulating free Alu DNA in endometrial cancer. Int J Gynecol Cancer 22: 82-86, 2012

53. Waki K, Yokomizo K, Kawano K, Tsuda N, Komatsu N and Yamada A: Integrity of plasma cell-free DNA as a prognostic factor for vaccine therapy in patients with endometrial cancer. Mol Clin Oncol 14: 29, 2021

54. Sikora K, Bedin C, Vicentini C, Malpeli G, D'Angelo E, Sperandio N, Lawlor RT, Bassi C, Tortora G, Nitti D, et al Evaluation of cell-free DNA as a biomarker for pancreatic malignancies. Int J Biol Markers 30: e136-e141, 2015.

55. Utomo WK, Janmaat VT, Verhaar AP, Cros J, Lévy P, Ruszniewski P, den Berg MS, Jenster G, Bruno MJ, Braat H, et al: DNA integrity as biomarker in pancreatic cyst fluid. Am J Cancer Res 6: 1837-1841, 2016.

56. Mead R, Duku M, Bhandari P and Cree IA: Circulating tumour markers can define patients with normal colons, benign polyps, and cancers. Br J Cancer 105: 239-245, 2011.

57. Leszinski G, Lehner J, Gezer U and Holdenrieder S: Increased DNA integrity in colorectal cancer. In Vivo 28: 299-303, 2014.

58. El-Gayar D, El-Abd N, Hassan N and Ali R: Increased free circulating DNA integrity index as a serum biomarker in patients with colorectal carcinoma. Asian Pacific J Cancer Prev 17: 939-944, 2016.

59. Bedin C, Enzo MV, Del Bianco P, Pucciarelli S, Nitti D and Agostini M: Diagnostic and prognostic role of cell-free DNA testing for colorectal cancer patients. Int J Cancer 140: 1888-1898, 2017.
60. Zhu F, Ma J, Ru D, Wu N, Zhang Y, Li H, Liu X, Li J, Zhang H, $\mathrm{Xu}$ Y, et al: Plasma DNA Integrity as a prognostic biomarker for colorectal cancer chemotherapy. J Oncol 2021: 5569783, 2021.

61. Soliman SES, Alhanafy AM, Habib MSE, Hagag M and Ibrahem RAL: Serum circulating cell free DNA as potential diagnostic and prognostic biomarker in non small cell lung cancer. Biochem Biophys Rep 15: 45-51, 2018.

62. Waki K, Yokomizo K, Yoshiyama K, Takamori S, Komatsu N and Yamada A: Integrity of circulating cell-free DNA as a prognostic biomarker for vaccine therapy in patients with nonsmall cell lung cancer. Immunopharmacol Immunotoxicol 43: 176-182, 2021.

63. Ren S, Ren X, Guo H, Liang L, Wei K, Guo L, Qu X, Dai X and Huang Q: Concentration and integrity indexes of urine cell-free DNA as promising biomarkers for early lung cancer diagnosis. Per Med 18: 129-139, 2021

64. Jiang P, Chan CW, Chan KC, Cheng SH, Wong J, Wong VW, Wong GL, Chan SL, Mok TS, Chan HL, et al: Lengthening and shortening of plasma DNA in hepatocellular carcinoma patients. Proc Natl Acad Sci USA 112: E1317-E1325, 2015.

(i) $\Theta$ This work is licensed under a Creative Common Attribution-NonCommercial-NoDerivatives 4.0 International (CC BY-NC-ND 4.0) License. 